\title{
Neonomics
}

Central European Review of Economics \& Finance

Vol. 26, No. 4 (2018), pp. 25-35

DOI: $10.24136 /$ ceref.2018.019

Received: 30 May 2018. Accepted: 30 August 2018.

Iwona KOWALSKA ${ }^{1}$

\section{CORRECTIVE ACTION PLANS FOR LOCAL GOVERNMENTS AS THEIR FINANCIAL HEALTH BAROMETERS?}

The implementation of corrective action plans in local government units (LGUs) takes place in the situation when they are unable to draw up a Multiannual Financial Forecast or the budget complying with the principles set out in Article 242-244 of the Public Finance Act (UFP). In the years 2012-2016, there was a six-fold increase in the number of LGUs which were obliged to implement these plans. Therefore, the aim of this paper is to assess their suitability as an actual barometer of the financial standing of local government units and propose an alternative solutions. The conducted analysis shows that the adopted legislative solutions regulating the implementation of corrective action plans are inconsistent and their effectiveness is not fully satisfactory. The paper suggests changes in current regulations and proposes alternative approach to the assessment of the financial position of local government units.

Keywords: finance, local government, debt, corrective action plan.

JEL Classification Codes: H6, H7, G28.

\section{Introduction}

The effective functioning of the local government finance system is not an end in itself. Finances are only a means to implement the main goals of local government (...), but are indispensable to achieve these goals (Malinowska-Misiag et al., 2015). Therefore, if the local government financial standing deteriorates, the quality of public services and the scope of these services delivered to local communities are also endangered. The reasons for the decline in the financial health of local government units (LGUs)

\footnotetext{
${ }^{1}$ Associate professor, Warsaw University of Life Sciences, Faculty of Economics.
} 
are very diverse. In the opinion of the Supreme Audit Office (NIK), the identification of uniform factors which determine the deterioration of LGUs financial standing is difficult due to their specificity. Deterioration of this situation results in the obligation to implement corrective actions. Local governments are obliged to implement corrective action plans for reasons that often originated in the years preceding their adoption. These reasons are usually of a long-term and often structural nature. But they may also include one-off situations, (e.g.: the fulfillment of obligations resulting from the concluded court settlement). However, the main reason for the deterioration of LGUs' financial standing is the 'investment spree' resulting from the availability of aid funds. In order to make investments co-financed from the EU funds, LGUs had to provide their own contribution financed by loans, credits or bond issue. This increased their indebtedness and aggravated the indicators monitoring their financial health. In 2012-2016, the number of LGUs implementing corrective action plans increased 6-fold, i.e. from 10 to 60 . The greatest increase in the number of self-governments implementing corrective action plans took place in 2014-2015. The corrective action plans were most often implemented by municipal and rural gminas (communes), and less frequently by powiats (districts). The voivodeships (provinces) in which LGUs implemented corrective action plans were evenly distributed across the country. The only exception was the Zachodniopomorskie voivodeship with the largest number of 16 local governments implementing corrective action plans. In four provinces (Wielkopolskie, Opolskie, Małopolskie, Lubelskie) LGUs did not implement corrective action plans. Therefore, the problem of the deteriorating financial health of local governments, which resulted in the need to implement corrective plans, concerned about $2 \%$ of all LGUs ${ }^{2}$. The aim of this paper is to assess the suitability of the LGU's corrective action plans as an actual barometer of their financial health and to suggest changes in this area. The study involves the critical analysis of legislation regulating self-government finance sector and the review of the literature. The analysis covers the period 2012-2016, which is identical to the period of an audit carried out by the Supreme Audit Office on the effectiveness of corrective action plans implemented in LGUs.

\section{Regulation of corrective action plans for LGUs in the Public Finance Act}

Contents of Article 240a of the Act of 27 August 2009 on Public Finance (UFP) (Journal of Laws of 2017, item 2077 as amended), specifies the consequences of noncompliance with the statutory limits on spending and incurring liabilities by LGUs. This provision was introduced in Article 1 point 19 of the Act of November 8, 2013 amending the Public Finance Act and some other acts (Journal of Laws, item 1646, as amended). This provision regulates the LGU's corrective proceedings in a situation when the Multi-

\footnotetext{
${ }^{2}$ As of January 1, 2017 there were 2808 LGUs in Poland. Information on local governments carrying out corrective action plans was collected as at the end of 2017.
} 
annual Financial Forecast (WPF) or the budget of LGUs cannot be drawn up in accordance with the principles set out in Articles 242-244 of the Public Finance Act. The occurrence of this situation obliges the College of the Regional Chamber of Audit (RIO) to summon the local government units to develop and adopt a corrective action plan within 45 days from the date of receipt of the request. The LGU's governing body shall adopt a corrective action plan for a period not exceeding three consecutive financial years. This plan should include in particular:

1) analysis of the financial standing of the local government unit (including the identification of the reasons for the threat to the implementation of public tasks);

2) a corrective action plan with an implementation schedule;

3) expected financial results of individual corrective actions along with the method of their measurement.

According to Article 240a, subsection 4 of the UFP the constituting body of LGU may enact the Multiannual Financial Forecast and the budget of the unit, which do not comply with the regulation on debt limit specified in Article 242-244 of the UFP during the implementation of the corrective action plan, which received a positive opinion of the Regional Chamber of Audit (RIO). However, the failure to comply with the regulation may only concern the repayment of liabilities existing on the day of adopting the corrective action plan. This article is not uniformly interpreted. According to J.M. Salachny the reservation formulated in the cited Article 240a, subsection 4 does not apply to loans granted from the state budget for the implementation of the corrective proceedings (Salachna, 2014). A different view on this issue has been expressed by the representatives of the Regional Chamber of Audit in Rzeszów. They passed a resolution which bans incurring liabilities, including a loan from the state budget for the implementation of a corrective action plan, if their repayment will result in breaching the regulation specified in Article 242-244 UFP (Uchwała Kolegium RIO...,2014).

During the period of implementing corrective proceedings, LGUs are not allowed to: 1) undertake new investments financed by a loan or issue of securities;

2) provide financial assistance to other local government units;

3) grant sureties, guarantees and loans;

4) incur expenditure on the promotion of the unit;

5) create a Municipal Fund (Municipal Fund comprises funds separated from the gmina's budget, guaranteed for the implementation of projects aimed at improving the living standard of residents) (Walczak, 2017).

\footnotetext{
${ }^{3}$ This is a problem of interpretation, because in the budget, investments are financed by capital expenditure. Assuming that the budget shows a deficit, while maintaining the requirement set in Article 242 of the UFP, the deficit may be financed, for example, by taking out a loan. As part of capital expenditure, to determine the acceptable level of incurring debt obligations, it will be necessary to identify continued and new investments. However, if the operating surplus can cover part of the capital expenditures, it is problematic to decide whether these expenses are related to new or continued investments.
} 
LGU is also obliged to limit the implementation of tasks other than mandatory and financed from own resources. It should also be noted that starting from the month following the month in which the corrective action plan was adopted, until the day the corrective procedures are completed, the amount of expenditure for:

1) remuneration of councilors,

2) remuneration of the LGU's management board,

cannot exceed the amount of expenditure incurred for this purpose in the year preceding the year in which the resolution regarding the corrective actions was taken.

In the period preceding the entry into force of Article 240a the corrective proceedings for LGUs were not regulated by generally applicable regulations (except for the reference in the contents of Article 224 of the UFP). However, it should be emphasized that the mentioned provisions of Article 224 and 240a of the UFP are not consistent. As a result, in the current legal status there are two modes of implementing corrective proceedings: pursuant to Article 224 of the UFP or pursuant to Article 240a of the UFP. According to the provisions of Article 224 of the UFP, LGU may be granted a loan from the state budget if:

1) LGU carries out a corrective action plan or proceeds to its implementation and

2) analysis of the corrective action plan shows that the following criteria will most probably be met:

a) Improvement of the financial health of the local government unit and its effectiveness in carrying out statutory tasks.

b) Principles set out in Article 242-244 UFP will be met at the end of the year in which the loan repayment deadline expires.

c) Loan repayment with interest will be secured.

The loan is interest-bearing and the interest rate is determined by the contract (Article 115, subsection 2 of the UFP). The loan and interest cannot be cancelled (Article 224, subsection 2 of the UFP). LGU submits a loan application to the Minister of Finance. The loan application must enclose the corrective action plan, documents containing data enabling the current and forecasted assessment of the financial standing of the entity as well as proposed collateral to secure the loan (Article 224, section 3 of the UFP). The Minister of Finance issued the Ordinance of December 23, 2010 on loans from the state budget granted to local self-government units as part of prudential or corrective proceedings (Journal of Laws No. 257, item 1730), which includes:

1) the detailed scope of data contained in the loan application,

2) list of documents to be enclosed in the application,

3 ) the type and scope of accepted collateral ${ }^{4}$.

\footnotetext{
${ }^{4}$ The catalogue of collaterals securing the loan is closed and comprises bank promissory notes or notarial act of submission to execution under Article 777, section 1, subsection 5 of the Act of November 17, 1964, the Code of Civil Procedure (Journal of Laws of 2016, item 101, as amended).
} 


\section{Conclusions from the audit on the implementation of corrective action plans in LGUs conducted by the Supreme Audit Office}

The Supreme Audit Office (NIK) audited the LGUs' corrective action plans mainly to check their compliance with Article 240a, subsections 2 and 3 of the UFP (period of development and content of the corrective action plan) The audit was carried out in 14 LGUs implementing 15 corrective action plans in the period 2012-2016 (Skuteczność programów naprawczych ..., 2017). It was also checked if the restrictions resulting from Article 240a subsections 5 and 6 of the UFP were observed. Furthermore, the audit verified if the causes of the deterioration of the financial standing of local governments were correctly identified as well as the feasibility of corrective actions with regard to the results to be accomplished. Their achievement was supposed to eliminate the threats to the implementation of public tasks and lead to compliance with the regulation specified in Articles 242 and 243 of the UFP. The consistency of data with the figures included in the Multiannual Financial Forecast (WPF) was also assessed. In the period under scrutiny, i.e. the years 2012-2016, the Minister of Finance granted corrective loans in the total amount of PLN 298.1 million to LGUs conducting or initiating corrective proceedings.

The audit carried out by the Supreme Audit Office (NIK) included both positive and negative assessments of the implementation of corrective action plans in local government units. The positively evaluated aspects included the fact that in the majority of audited local governments the condition specified in Articles 242-243 of the UFP was met. This means that almost all of the controlled corrective action plans have resulted in the improvement of the financial health of LGUs. Nevertheless, due to the short period of time which passed between the completion of the corrective actions (most often in 2016) and the audit, NIK refrained from determining if the results were lasting. The positive outcome achieved by LGUs was partly determined by the loans granted by the Minister of Finance. The loan applications were subject to a thorough verification regarding the reliability of the information provided by local government units. The loans served to eliminate the main causes for the deterioration of the financial health of the audited entities. Taking out loans from the state budget was economically beneficial for local governments as debt maturity dates have been extended, and annual debt service expenditure has been reduced. The Minister of Finance also monitored the use of loans by LGUs. To this end, fiscal controls were carried out at LGUs and the LGUs' compliance with the ban on incurring debts without the prior written consent of the Minister of Finance was monitored.

In the quoted report on the effectiveness of corrective action plans implemented in LGUs the following aspects were negatively evaluated:

\footnotetext{
${ }^{5}$ Gmina Pęcław implemented the first corrective action plan in 2014 and in the years 2016-2017 the second corrective action plan.
} 
1. Lack of determination of the expected financial results of part of corrective actions and/or the measurement methods. Failure to meet these requirements was inconsistent with UFP regulations. Over half of the controlled corrective actions did not achieve the planned financial results. The corrective action plans most often assumed that the taken actions would result in a reduction in expenditure and an increase in budget revenues.

2. Failure to comply with statutory limitations resulting from the implementation of corrective action plans. This, however, did not affect the effectiveness of the carried out actions. During the implementation of corrective action plans, $21 \%$ of audited local government units, incurred expenditures on promotion in the total amount of PLN 57.6 thousand which breached the regulation set out in Article 240a, section 5, subsection 4 of the UFP.

3. Failure to limit the implementation of tasks other than mandatory, financed from own resources, thereby violating Article 240a, section 5, subsection 6 of the UFP and incurred expenditure in the total amount of PLN 254.5 thousand.

4. Failure to develop reliable corrective action plans (this concerned less than half of the audited plans). A recurrent irregularity was the failure to specify what financial results should be achieved by the corrective actions and how they would be measured, which was inconsistent with Article 240a, section 3, subsection 3 of the UFP.

5. Discrepancies in the assessments of corrective action plans carried out by the Supreme Audit Office (NIK) and Regional Chambers of Audit (RIO). This situation concerned $43 \%$ of cases of audited LGUs. These discrepancies regarded the assessment of non-compliance of the corrective action plans with the UFP regulations.

6. Irregularities in financing the development of corrective action plans in the amount of PLN 51.6 thousand (in the first case, the expenditure was inconsistent with the authorization defined in the budget resolution, in the second case - the internal procedures for awarding public contracts were not respected).

7. Failure to meet deadlines in the implementation of corrective actions specified in most corrective action plans. In $71 \%$ of audited LGUs, the corrective actions were delayed or their implementation was cancelled.

\section{Proposed changes in the assessment of the financial position of local government units resulting in the implementation of corrective action plans}

If we assume that the obligation to implement corrective action plans by LGUs is a legislative and real proof of their difficult financial position and, as concluded by the Supreme Audit Office, the adopted scope of these actions is not fully satisfactory; an attempt may be made to suggest changes to the assessment of LGUs' financial standing. These proposals could be divided into two groups. The first group would be characterized by an evolutionary approach to change. It could include a proposal to change the 
scope of competencies related to the supervision of LGUs as well as an amendment to the currently applicable provisions regarding the corrective action plans. The second group would include changes of a more revolutionary nature (i.e. the introduction of new regulations that would radically change the current conceptual approach).

In the first case, there would be changes in the division of competences regarding the supervision of LGUs between the Prime Minister, voivodes (province governors) and Regional Chambers of Audit (RIO). Pursuant to the currently binding regulations, this supervision over LGUs is not cohesive. The tasks in the field of financial supervision over LGUs should be performed by the RIO. Resolutions on the adoption of corrective action plans are in turn partially reviewed by voivodes, but only in cases where local governments apply for loans granted from the state budget. In this case, the voivode issues an opinion on the projects proposed for implementation by local government units as part of the corrective proceedings as regards the compliance with the law of the planned corrective actions. RIOs provide voivodes with information on the financial standing of local governments, mainly in the cases when LGUs are threatened with being placed into receivership or when RIOs negatively evaluate LGU's budget implementation reports and information on the status of LGU's property. However, these are all ex post-facto actions. Thus, the reliability of the implementation of the adopted assumptions of corrective action plans is not verified by any supervisory authority. On the other hand, voivodes do not generally collect information on the financial position of local governments operating in their territories, and thus they do not monitor the implementation of LGUs' corrective action plans. However, it should be remembered that in addition to compliance with the regulations set out in Articles 242 and 243 of the UFP, which is monitored by the RIOs, the essence of the corrective action plan is the elimination of the threat to the implementation of public tasks, including tasks ordered by the voivode. Therefore, situations may arise in which voivodes find out about the bad financial situation of local governments only when it is necessary to place them into receivership. Consequently, the obligation to draw up annual reports on the implementation of corrective action plans should be considered. These reports should be submitted to RIOs and voivodes to ensure ongoing monitoring of the financial health of local governments, accurate implementation of corrective actions set out in the corrective action plans, as well as compliance with statutory prohibitions and restrictions on local government activities resulting from the adoption of corrective action plans.

The first group of proposed changes should also include amendments to the currently binding provisions on corrective action plans which would regard the following aspects: 1. Interpretation of Article 240 a, subsection 6 of the UFP. A teleological interpretation of this provision indicates that the expenditure regime may only apply to those components which are incurred upon the employer's decision, (but it should apply to expenditure arising from employees' entitlements like seniority bonuses, additional annual remuneration, severance pay in connection with retirement or disability benefit). Consequently, 
it should refer to the prohibition of increasing expenditure on basic pay, special allowances and functional benefits.

2. Inconsistencies in the provisions of Article 224 and 240a of the UFP regarding:

2.1. The period for which a corrective action plan may be approved with the period for which a loan from the state budget may be granted;

2.2. Failure to use loans from the state budget by self-governments carrying out corrective action plans - it should be clarified that the loan granted from the state budget is not subject to the restrictions on incurring new liabilities;

2.3. Failure to determine the procedure for early closure of corrective actions and no interpretation regarding the final closure of a corrective action (i.e. what date / period should be adopted in this case);

2.4. Determining the possibility of introducing changes in the course of the implementation of corrective action plans, specifying in which situations and in what mode they can be made / reviewed and which elements of the corrective action plans may be adjusted. 3. Imprecise provision of Article 240a, subsection 5, point 5 of the UFP on the prohibition of the creation of a Municipal Fund by LGUs during the corrective proceedings. The Municipal Fund is created much earlier (the self-governing body decides to separate the fund by 31 March of the year preceding the year for which the fund is established) compared to the corrective action plan. In the light of the above, it seems that the intention of the discussed instruction is first of all the prohibition of disbursement of funds from the Municipal Fund, which should however be clarified, by the legislator. It should be enacted that during the implementation of the corrective action plan, new expenditure from the Municipal Fund created before the plan was adopted is banned. Consequently, amendments should be made to the content of the Act of 21 February 2014 on the Municipal Fund (Journal of Laws of 2014, item 301, as amended). The new regulation should provide that tasks initiated before the adoption of the corrective action plan could be completed during its implementation

4. Clarification in the content of Article 240a subsection 6 of the UFP specifying which expenditure related to remuneration of councillors and LGU's management board may not exceed the legally binding limit.

As for the changes of more revolutionary character, an alternative approach to assessing the financial health of LGUs could go beyond checking compliance with the regulation provided in Articles 242-244 of the UFP. In this context, the implementation of corrective action plans in LGUs could be considered in the case of:

1) mismanagement of free reserves;

2) incurring liabilities with the use of non-standard debt instruments increasing the actual debt.

Mismanagement of free reserves refers to the content of Article 217, subsection 2, point 6 of the UFP. It defines free reserves as a surplus of cash in the current account of the LGU's budget, resulting from settlements of issued securities, credits and loans from 
previous years. It can be concluded that the free reserves include the funds defined in Article 2017 of the UFP from 2009, as well as funds coming from the undistributed cumulative budget surplus and other available funds from a given period, except the funds from the state budget subsidy (Rutkowska-Tomaszewska, 2012). If the free reserves are not taken into account as a source of funding to close the budget gap and instead new loans are incurred and securities issued for the same purpose, such actions may be considered doubtful with regard to good practices in public financial management and fiscal prudence ${ }^{6}$. It should be noted that the management of public funds is subject to the budgetary discipline regulations, that is, the obligation to observe the principles of legality and economic efficiency defined by law (Chojna-Duch, 2003).

The financial situation of LGUs is also affected by entering into contracts for so-called non-standard debt instruments. Their use is permitted by the Regulation of the Minister of Finance of December 28, 2011 on the detailed manner of classifying debt titles classified as state public debt (Journal of Laws of 2011, No. 298, item 1767), which in its content lists a catalogue of debt items classified as state-owned public debt. Local and regional authorities take various methods to circumvent statutory debt regimes. They include:

1) Concluding false debt assumption and debt restructuring agreements.

2) Concluding factoring agreements. Pursuant to the definition adopted by the Convention on International Factoring (Ottawa 1988) the factoring company is to perform at least two of the following functions:

- finance for the supplier, including loans and advance payments

- maintenance sales ledger

- collection of receivables

- protection against default in payment by debtors (Filipiak, Zioło, 2016).

3) Other quasi-financial products with the features of repayable financing instruments: subrogation, return sale and leaseback.

By not including the non-standard debt instruments into debt, the LGU increases its actual indebtedness, leading to a situation where it may not be able to draw up the Multiannual Financial Forecast or the budget complying with the principles set out in Articles 242-244 of the UFP. The RIO report of 2016 titled: 'Non-standard financing instruments for budgetary needs of local government units' shows that LGU's liabilities total PLN 274.5 million (including main receivables and any side receivables related to a given instrument, for example, rent, interest, commissions, leasing installments, repayment deposits, etc.).

\footnotetext{
${ }^{6}$ Legitimate reasons for the application of this solution may apply to exceptional situations e.g. securing funds for pending lawsuits and appellations which may result in urgent payments or tax refunds
} 


\section{Summary and Conclusions}

The conducted analysis demonstrates that the assessment of the legislative framework for the local governments' corrective action plans in the context of their suitability as an actual barometer of LGU's financial health is not unambiguously positive. Launching corrective action plans in cases like the inability to draw up a Multiannual Financial Forecast or the budget complying with the principles set out in Articles 242-244 of the UFP seems to be insufficient. Hence the proposed solutions representing evolutionary and revolutionary approaches to legislation regulating LGU's financial position assessment procedures. The evolutionary approach requires a sufficient number of votes to enact the amendments to the existing legal acts in the parliamentary procedure and the signature of the president. However, in order to implement the proposed solutions of a more fundamental and revolutionary nature, a much more important condition than the support on the legislative path will have to be met. The local government finance system should be reviewed in an unconventional way from an interdisciplinary perspective. Therefore, further efforts to work out detailed solutions within the proposed framework, should be supported by academic environments representing various scientific disciplines.

\section{References}

Chojna-Duch E. (2003). Polskie prawo finansowe, finanse publiczne. LexisNexis, Warszawa, p. 124.

Filipiak B.Z., Zioło M. (Eds.) (2016). Współpraca jednostek samorządu terytorialnego z instytucjami finansowymi. Difin, Warszawa, p. 179.

Malinowska-Misiag E., Misiag J., Misiag W., Rodzinka J., Skica T., Tomalak M. (2015). Finanse samorządowe - stan, perspektywy, zagrożenia. Instytut Badań i Analiz Finansowych, Rzeszów, p. 2.

Niestandardowe instrumenty finansowania potrzeb budżetowych jednostek samorządu terytorialnego (2016). Krajowa Rada Regionalnych Izb Obrachunkowych, Łódź, pp. 23 - 31.

Rozporządzenie Ministra Finansów z dnia 23 grudnia 2010 r. w sprawie pożyczek z budżetu państwa udzielanych jednostkom samorządu terytorialnego w ramach postępowań ostrożnościowych lub naprawczych (Dz. U. Nr 257, poz. 1730).

Rozporządzenie Ministra Finansów z dnia 28 grudnia 2011 r. w sprawie szczegółowego sposobu klasyfikacji tytułów dłużnych zaliczanych do państwowego długu publicznego (Dz. U. $2011 \mathrm{Nr}$ 298, poz. 1767).

Rutkowska-Tomaszewska E. (2012). Lokowanie wolnych środków przez jednostki samorządu terytorialnego w bankach. Finanse Komunalne No. 4, p. 26. 
Salachna J.M. (2014). Postępowanie naprawcze jednostki samorządu terytorialnego - wybrane problemy interpretacyjne. Prawo Budżetowe Państwa i Samorządu 1(2), p. 17.

Skuteczność programów naprawczych jednostek samorządu terytorialnego (2018). KBF.430.014.2017, Nr ewid. 180/2017/P/17/009/KBF. NIK, Warszawa, pp. 5; $12-47$.

Uchwała Kolegium RIO w Rzeszowie z dnia 8 kwietnia 2014 r., IX/1674/14.

Ustawa z dnia 8 listopada 2013 r. o zmianie ustawy o finansach publicznych oraz niektórych innych ustaw (Dz. U. poz. 1646, ze zm.).

Ustawa z dnia 17 listopada 1964 r. Kodeks postępowania cywilnego (Dz. U. z 2016 r. poz. 101, ze zm.).

Ustawa z dnia 21 lutego 2014 r. o funduszu sołeckim (Dz. U. z 2014 r. poz. 301, ze zm.).

Ustawa z 27 sierpnia 2009 r. o finansach publicznych. (tj. Dz.U. z 2017 r. poz. 2077 ze zm.).

Walczak P. (Ed.) (2017). Ustawa o finansach publicznych Komentarz dla jednostek samorządowych. C.H. Beck, Warszawa, pp. $719-720$. 